\title{
ARTIFICIAL PERCHES FOR ECOLOGICAL RESTORATION: CONTRIBUTIONS OF BRAZILIAN UNIVERSITIES
}

\author{
Huilquer Francisco Vogel \\ Ana Paula Weiwanko** \\ Jairo José Zocche****
}

\begin{abstract}
The use of artificial perches as a nucleation technique is an alternative method of promoting the low-cost restoration of degraded environments in a short period of time. To better understand the results obtained from the use of artificial perches, this study aimed to: (1) quantify, (2) spatialize and (3) synthesize Brazilian academic literature concerning environmental restoration projects that used artificial perches. Twenty studies carried out between 1997 and 2014 were identified from several universities. Among them, $40 \%(n=8)$ were undergraduate papers written at the end of the respective course, 35\% $(n=7)$ constituted Master's dissertations, $15 \%(n=3)$ were Doctoral thesis, and $10 \%(n=2)$ were monographs' specialization. This research was distributed over four terrestrial Brazilian biomes, with $60 \%(n=12)$ of the studies carried out in the Atlantic Rainforest biome and $20 \%(n=4)$ in the Cerrado biome. The rate of publication was 1.17 per year, which demonstrates that studies on artificial perches in nucleation are scarce. Although most of the analyzed documents emphasized increased deposition of seeds under the perches, it is necessary to improve understanding of ecological filters in limiting the establishment of post-dispersal seedlings.
\end{abstract}

KEY WORDS: Nucleation; Avian fauna; Seed rain.

\section{USO DE POLEIROS ARTIFICIAIS PARA A RESTAURAÇÃO ECOLÓGICA: CONTRIBUICÕES DAS UNIVERSIDADES BRASILEIRAS}

RESUMO: O uso de poleiros artificiais como técnica nucleadora é uma opção para promover a restauração de ambientes degradados em curto prazo e a baixo custo. Buscando compreender melhor os resultados obtidos com a utilização de poleiros artificiais, este trabalho teve como objetivo: (1) quantificar, (2) espacializar e (3)

\footnotetext{
Doutor em Ciências Ambientais, docente permanente do curso de Ciências Biológicas da Universidade Estadual do Paraná - UNESPAR, Brasil. E-mail: huilquer@hotmail.com

** Licenciada em Ciências Biológicas na Universidade Estadual do Paraná - UNESPAR, Brasil.

*** Pós-Doutor em Biologia da Conservação, docente permanente do Programa de Pós-graduação em Ciências Ambientais - PPG-CA da Universidade do Extremo Sul Catarinense - UNESC, Brasil.
} 
sintetizar estudos sobre restauração ecológica realizados no Brasil, que utilizaram poleiros artificiais como estratégia nucleadora. Revisando documentos disponíveis em diversas instituições de ensino, foram encontrados 20 diferentes estudos realizados entre 1997 e 2014. Destas pesquisas, 40\% $(n=8)$ foram trabalhos de conclusão de curso, $35 \%(\mathrm{n}=7)$ constituíam-se de dissertações de mestrado, uma proporção menor, $15 \%(n=3)$ está representada por teses de doutorado e $10 \%(n$ $=2$ ) por monografias de especialização. As pesquisas estão distribuídas em quatro biomas terrestres do Brasil, com predomínio de estudos realizados na Mata Atlântica $(\mathrm{n}=12) 60 \%$ e Cerrado $(\mathrm{n}=4)$ 20\%. Em um recorte temporal de 17 anos, a taxa de trabalhos/ano encontrada é 1,17, o que demonstra que o estudo da utilização de poleiros artificiais como técnica nucleadora na restauração de áreas degradadas é baixo. Ficou diagnosticado que embora a maior parte dos documentos analisados seja contundente em ressaltar o aumento na deposição de sementes sob os poleiros artificiais, é necessário avançar na compreensão sobre o efeito de filtros ecológicos que limitam o estabelecimento de plântulas pós-dispersão.

PALAVRAS-CHAVE: Nucleação; Avifauna; Chuva de sementes.

\section{INTRODUCTION}

To compensate habitat loss caused by anthropic activities, mainly those related to agriculture/livestock-raising, mining, and urbanization, a theoretical debate has arisen and has stimulated new ecological restoration strategies. These strategies are mainly focused on the restoration of ecological relationships and/or functions, creating greater stability in recently-restored habitats (REY-BENAYAS et al., 2008; REIS et al., 2014). Many of the new restoration approaches are based on the creation of vegetation nuclei (nucleation), which permit the establishment of plant and animal species through facilitation principle (YARRANTON; MORRISON, 1974; ZAHAWI et al., 2012).

Plant ecological succession is the result of vegetation dynamics in response to the different capacities of plants to establish in specific places, a product of stochastic events that create many trajectory possibilities and landscape heterogeneity (CADENASSO et al., 2006; RODRIGUES et al., 2009). Ecological succession does not follow an obvious pattern, mainly due to stochasticity and randomness brought 
about by environmental vectors, which tend to increase habitat richness (REYBENAYAS et al., 2008). Thus, environmental vectors assume great importance in the courses of ecological succession (LUNDEBERG; MOBERG, 2003).

The Society for Ecological Restoration (SER) defines ecological restoration as "the science, practice, and art of watching and managing the recuperation of the ecological integrity of ecosystems, including a minimum level of biodiversity and variability in the structure and function of ecological processes, considering its ecological, economic and social values" (SER, 2004). Although there are critics of this concept, ecological restoration is more than the single application of a set of techniques aiming to recover the structure and function of a degraded area; it is also a new philosophy of environmental management and restoration.

Many recent studies have focused on the biocentric principles of restoration, especially on the use of nucleation techniques, such as soil transposition, windrowing of brushwood, planting of seedlings in groups (islands of vegetation), and insertion of perches for the fauna (REIS et al., 2007; REIS et al., 2010). Among these techniques, artificial perches imitate dry trees in the landscape in order to attract birds (GUEDES et al., 1997). Birds deposit seeds underneath perches after feeding on nearby fruit fragments (HOLL, 1998; CAMPOS et al., 2012).

Thus, perches attract birds, which then stay on the perches long enough to defecate or regurgitate seeds ingested in forests (SHIELS; WALKER, 2003; SHELDON; NADKARNI, 2013). Therefore, birds act decreasing one of the greatest limitations in the restoration of degraded environments: the arrival of seeds (PIZO et al., 2004; PEJCHAR et al., 2008; McCARRON, 2016).

The use of artificial perches in the restoration of degraded areas has increased because of their many advantages; these include their low cost and high efficiency at increasing the seed rain of autochthonous and allochthonous species, increasing gene flow in the area under restoration (TRES et al., 2007; BOCCHESE et al., 2008). In addition to serving as propagules for the recomposition of the seed bank, the seeds provide a food source for secondary dispersers or seed predators (CAMPOS et al., 2012), promoting the continued existence of the fauna at this site and gradually reconstituting the structure of trophic webs and ecosystem stability (TRES et al., 2007; REIS et al., 2010). 
Dry perches, living perches, and aerial cables enable birds to use these sites as a foraging area, rest site, and stepping-stone sites, maximizing ecosystem services for the predation of undesirable animals and seed dispersal in areas under restoration processes (REIS et al., 2003; SILVA et al., 2010).

Most studies involving nucleation techniques, developed between 1996 to 2012, have been performed in Brazil (BOANARES; AZEVEDO, 2014). Hypothetically, the number of published studies using perches could be higher; however, not all monographs, theses, and dissertations are effectively converted into published scientific articles. Therefore, the objective of this study was to: (1) quantify studies performed in Brazil involving artificial perches published as monographs, theses, and dissertations; (2) verify the distribution of these studies in terms of terrestrial ecoregions, Brazilian biomes, and universities; (3) synthesize the main results of these studies, which often remain unknown because they are not published in specialized journals. This analysis should provide a summary of the role of artificial perches in ecological restoration by means of nucleation in altered landscapes.

\section{MATERIALS AND METHODS}

\subsection{DATA COLLECTION}

The software program Publish or Perish ${ }^{\odot}$ was used to obtain bibliographies (HARZING, 2007). This software is a research tool that uses the Google Scholar databank and identifies documents available on the websites of different universities. This research was conducted using the general search option in the program. Terms searched as key words were: (i) artificial perches + birds; (ii) dry perches + birds (in Portuguese and English). Only studies performed in Brazil with the objective of promoting the restoration of altered ecosystems were considered.

\subsection{DATA ANALYSIS}

The following were selected: first: monographs (undergraduate and 
specialized monographs); second: Master's dissertations; third: Doctoral theses, all developed up to the end of 2014. Some of these studies were also published later as scientific articles. In this case, priority was given to the earlier document. Basic data were collected by direct analysis of the documents (e.g. author, year, and research site, university where the study was developed, and natural characteristics of the studied environment). Subsequently, ecoregions of the Brazilian territory were identified based on the classification of Olson et al. (2001). The universities were plotted by Brazilian geopolitical regions (IBGE, 2015), to indicate the regions with the greatest number of studies.

\section{RESULTS}

Twenty studies carried out between 1997 and 2014 that used artificial perches as a nucleation technique for the restoration were identified. Among these, 40\% (n $=8)$ were undergraduate monographs, $35 \%(\mathrm{n}=7)$ were Master's dissertations, $15 \%(n=3)$ were Doctoral Theses, and 10\% $(n=2)$ were specialized monographs. The studies were performed in eight states, with the highest number of studies performed in Paraná state $(\mathrm{n}=5)$. Regionally, the situation was as follows: South, 55\% $(\mathrm{n}=11)$; Southwest, 30\% $(\mathrm{n}=6)$; Midwest, $10 \%(\mathrm{n}=2)$, and Northeast, $5 \%$ $(\mathrm{n}=1)$. More details are provided in Figure 1. 


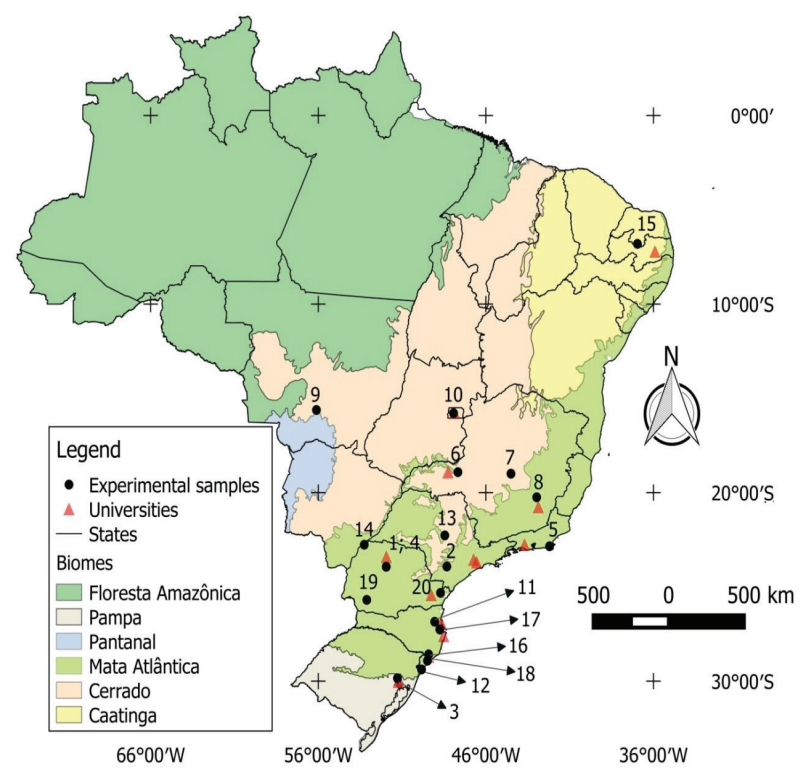

Figure 1. Distribution of the experimental sites and universities in the states and biomes of Brazil

The studies were performed in four terrestrial biomes in Brazil, with a predominance of studies carried out in the Atlantic Rainforest $(60 \% ; \mathrm{n}=12)$ and the Cerrado (20\%; $n=4)$. Only one study was developed in each of the Caatinga and Pampa biomes. Three records were obtained for ecotone areas, mainly in the transition zone with the Atlantic Rainforest biome. Most studies $(35 \% ; n=7)$ were recorded in the Serra do Mar coastal forests ecoregion. Six studies (33.33\%) were carried out in the Araucaria moist forests (three specific studies and three in ecotone areas). Details are provided in Table 1. Among the main ecoregional factors that changed the environments where the restoration studies were developed were: plant extractivism, mineral exploitation, agriculture, and livestock raising (Table 1). Most of the studies $(60 \% ; n=12)$ aimed to understand seed rain patterns and plant establishment, whereas 35\% $(n=7)$ assessed bird assemblage and seed rain. A single study dealt exclusively with the bird assemblage (Table 1). 
Table 1. Synthesis of the main results per category of studies that used artificial perches developed in Brazil. PR corresponds to the type of soil use that precedes restoration and BE corresponds to, respectively, the biome and specific ecoregion in which the work was developed. The numbers between parentheses represents the map' codes. More details in Appendix 1

\begin{tabular}{|c|c|c|}
\hline Monographs & Master's dissertation & Doctoral theses \\
\hline 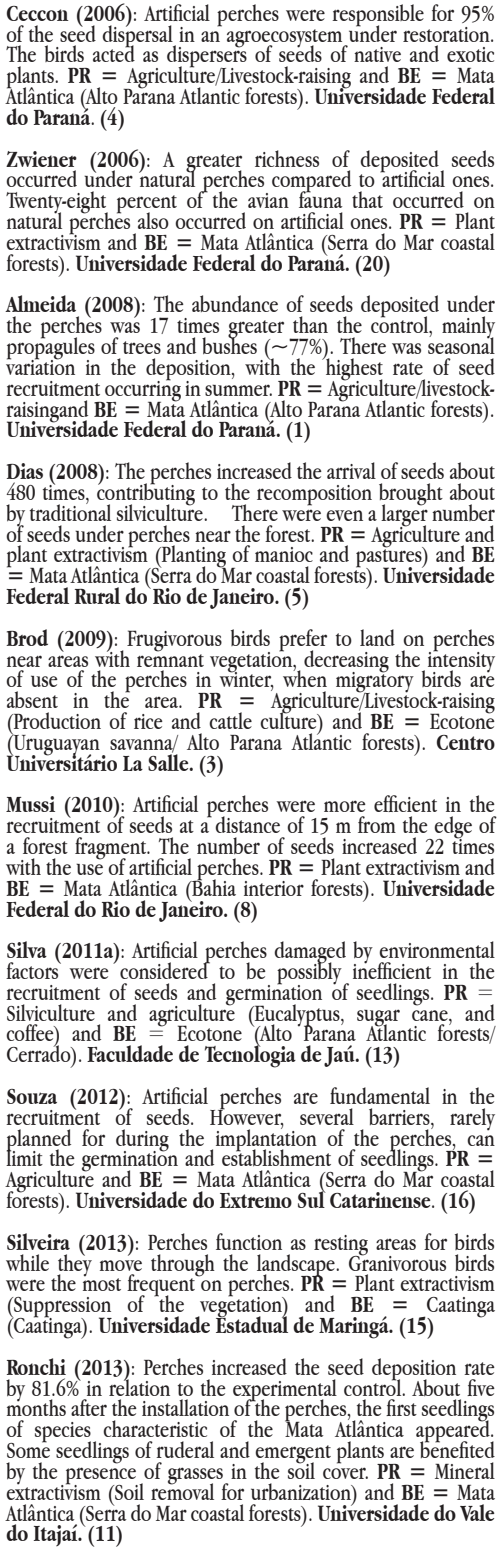 & 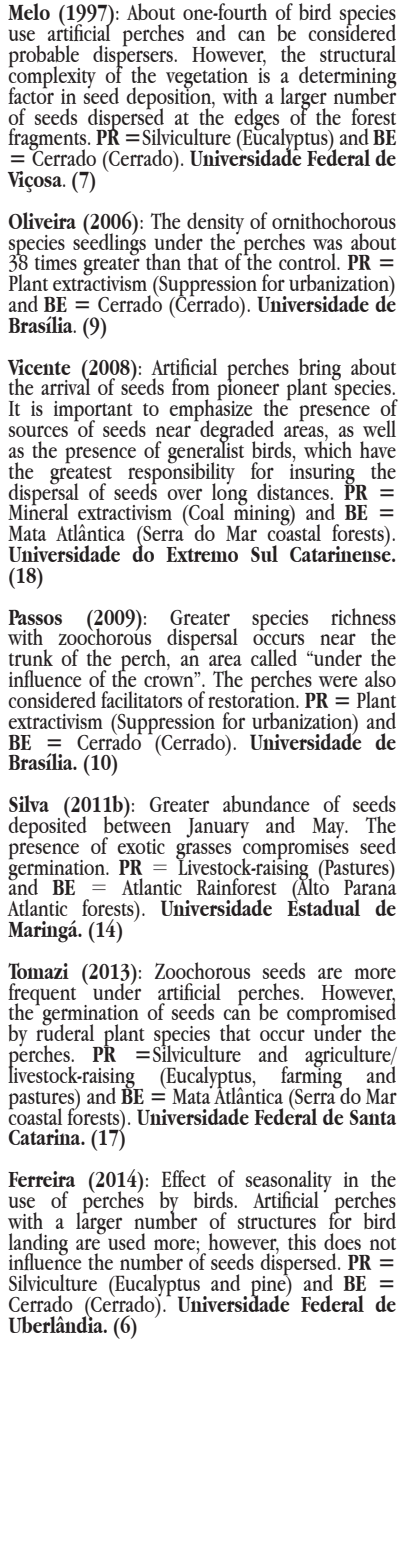 & $\begin{array}{l}\text { Bechara (2006): Between } 39 \text { and } \\
44 \% \text { of the bird species occurring } \\
\text { on artificial perches can promote } \\
\text { seed dispersal. The perches were } \\
\text { capable of increasing the recruitment } \\
\text { of seedlings that did not occur at the } \\
\text { site demonstrating the efficiency } \\
\text { of birds as vectors of propagules. } \\
\text { PR = Silviculture (Eucalyptus) and } \\
\text { BE =Ecotone (Alto Parana Atlantic } \\
\text { forests/Cerrado). Universidade de } \\
\text { São Paulo. (2) } \\
\text { Silva (2008): Artificial perches were } \\
\text { decisive in the deposition of seeds, } \\
\text { so that abundance and dispersed } \\
\text { species richness were greater in } \\
\text { spring and summer, indicating } \\
\text { that deposition accompanies the } \\
\text { phenological cycle. PR = Plant } \\
\text { extractivism (Palm heart) and BE = } \\
\text { Mata Atlântica (Serra do Mar coastal } \\
\text { forests). Universidade Federal do } \\
\text { Rio Grande do Sul. (12) } \\
\text { Vogel (2014): There was variation } \\
\text { in the richness and abundance of } \\
\text { birds that are potentially dispersers } \\
\text { between seasons, with tendencies for } \\
\text { increase in the estimates obtained in } \\
\text { the spring and summer. The perches } \\
\text { inefficiently attracted specialized } \\
\text { frugivorous birds, reinforcing that } \\
\text { the dispersal of seeds tends to be } \\
\text { carried out mainly by generalist } \\
\text { omnivores. PR = Agriculture/ } \\
\text { livestock-raising (Planting of corn, } \\
\text { soybeans and pastures) and BE } \\
=\text { Mata Atlântica (Araucaria moist } \\
\text { forests/ Alto Parana Atlantic forests). } \\
\text { Universidade Estadual de Maringá. } \\
\text { (19) }\end{array}$ \\
\hline
\end{tabular}




\section{DISCUSSION}

Over 17 years, studies were performed at a rate of 1.17 per year. This demonstrates that studies on the use of artificial perches in restoration projects are infrequent. The estimated time taken for these studies to be published as scientific articles is imprecise, because publication can take years after monographs, theses, and dissertations have been written.

Based on the methodology used in the present analysis, until 2006, only one study had investigated the use of perches in restoration, which was carried out by Mello et al. (1997) (Appendix 1). Most of the studies were carried out in the last decade; this is due to the increased number of degree courses and postgraduate study programs available in Brazil (SANTOS; AZEVEDO, 2009; MANCEBO et al., 2015). Thus, the predominance of works written at the end of undergraduate courses is likely to represent the recent establishment of young researchers. In addition, there is overlap of study sites (in some cases, more than one study per university; Table 1), demonstrating the continuation of research under the same advisor or the establishment of research groups (BOANARES; AZEVEDO, 2014).

Considering that artificial perches can be considered a link between ornithology and forestry sciences, explaining the large number of studies in the Atlantic Rainforest biome by factors previously presented in ornithology studies becomes useful. First, most of the human resources in ornithology are from the Southeast and South (BORGES, 2008; ALVES et al., 2008). This fact has led to more research centers in an urbanized strip that coincides with the geographical boundaries of the Atlantic Rainforest one of the 34 most threatened biodiversity hotspots in the world (MYERS et al., 2000; MYERS, 2003). It should also be emphasized that Atlantic Rainforest and Pampa shelter $70 \%$ of the Brazilian population and the greatest industrial poles of Brazil. The average density of the Brazilian coastal zone is 87 inhabitant $/ \mathrm{km}^{2}$, which is five times the national average, at around $17 \mathrm{hab} / \mathrm{km}^{2}$ (MMA/SBF, 2002). Thus, forest fragmentation in the Atlantic Rainforest biome requires greater technical and scientific efforts to develop ecological restoration studies, which aim to minimize the effects of fragmentation and habitat loss. 
Studies carried out in other biomes are also under high anthropic pressure, e.g., the Cerrado (FRANÇOSO et al., 2015). This importance of each biome study using artificial perches to demonstrate specific processes should be stressed, such as the presence of bird species that act as effective dispersers and are exclusive to a particular biome, allowing the preparation of specific management strategies. Recently, a greater deposition of seeds under artificial perches compared with natural perches was observed in the Brazilian Cerrado (FERREIRA; MELO, 2016). Therefore, it is important to identify habitat conditions that affect the germination and recruitment of seeds exposed to water stress, which is a typical characteristic of the Cerrado ecoregion.

Spatial distribution analysis of the analyzed studies indicated that only one study was performed in the Caatinga biome and none were performed in the Amazon Forest, Pampa, or Pantanal biomes (Figure 1). Of note, there are gaps in the methodology used to obtain data; studies have been performed in the Amazon Forest using artificial perches (e.g., BENTO et al., 2013), but these were not detected by the methodology applied. The general synthesis of the studies (published works; Table 1) shows that artificial perches imitate dry tree branches physically and functionally, and direct seed rain to a specific place (GUEDES et al., 1997; HOLL, 1998). Analysis of studies (Table 1) showed that seed rain tends to vary and is not necessarily greater when near the edge of forest fragments (DIAS et al., 2014). This pattern depends on the complexity of the vegetation, with a tendency for dispersal to decrease with advancing forest succession (BOCCHESE et al., 2008). It also depends on the assemblage of generalist birds, whose biological characteristics permit them to occupy open habitats, dispersing seeds beyond the edge of the source fragment (VICENTE et al., 2010).

Another aspect related to the synthesized data is that the frequency of birds on perches tends to be seasonal, with greater richness and abundance of potential disperser species in summer and spring in subtropical regions (VOGEL et al., 2016). This accompanies the phenological cycle of the vegetation (TOMAZI et al., 2010; HARTZ et al., 2012), which is influenced by generalist migratory birds that perform the ecosystem function of dispersal and, especially, by the fact that frugivorous birds are rarely present in unstructured environments (MELO et al., 2000; CAMPOS et al., 
2012).

Analysis of studies revealed that artificial perches effectively increase seed rain in relation to the experimental controls (SHIELS; WALKER, 2003). Under the perches, there is a predominance of seeds from trees, herbs, and lianas with the ornithochorous dispersal syndrome (PILLATT et al., 2010). The dispersal of exotic seeds can occur under some circumstances, which compromises the quality of the vegetation regenerated under the perches and the direction of forest regeneration (MARCUZZO et al., 2013).

Although most of the analyzed studies emphasize increased seed deposition under the perches, the establishment of seedlings is limited by post-dispersal environmental filters, such as the secondary predation of seeds e.g. action of granivorous birds (CHRISTIANIN; GALETTI, 2007), soil dissection (SILVEIRA et al., 2015), herbivory and damage by defoliator species (VAN-ANDEL; ARONSON, 2012), and competition from native and exotic grasses (CÉSAR et al., 2014).

In summary, analysis of available studies (Table 1) indicated that some gaps exist on the use of artificial perches, mainly a lack of studies related to procedures to increase the recruitment of seedlings under perches. There is a need to advance methodological techniques, such as estimating the optimum perch density in the landscape (SILVA et al., 2010), and type and ideal height of perches (DIAS et al., 2014). Greater efforts are needed to understand the capacity of perches to increase habitat complexity (MELO et al., 2000), because in addition to seed dispersal, perches can play a role in the reintroduction of fauna, inducing increases in the local richness of birds (HORGAN et al., 2016).

\section{CONCLUSION}

Most of the studies analyzed (total $=20$ ), developed as monographs, theses, and dissertations were recent (beginning in 1997), and most were devoted to the restoration of the Atlantic Rainforest biome, mainly in the Serra do Mar coastal forests and Alto Paraná ecoregions. The studies contain relevant information for the restoration of the Atlantic Rainforest and the Cerrado biomes. Most of the 
data are corroborated by the published literature. However, the increased amount of new information, mainly for the Caatinga, Amazon Forest, Pampa, and Pantanal biomes, could support restoration according to the specifics of the Brazilian biomes. Furthermore, they may help to provide an overview of the use of artificial perches in restoration by nucleation. Thus, the present analysis may be used to support the implantation of perches and demonstrate their important aspects to restore degraded environments.

\section{ACKNOWLEDGMENTS}

We thank the Universidade Estadual do Paraná (UNESPAR) for logistical, institutional, and financial support (protocol no. 651.12.03.2014).

\section{REFERENCES}

ALVES, M. A. S.; SILVA, J. M. C.; COSTA, E. S. Brazilian Ornithology: History and Current Trends. Ornitologia Neotropical, Montréal, v. 19, n. 1, p. 391-399, 2008.

BENTO, R. A.; VIEIRA, G.; PANHOCA, L.; CARNEIRO, L. M.; GUERRA, C. M. S. Custeio das atividades das técnicas de nucleação implantadas nas clareiras abertas pela exploração petrolífera na Amazônia central. Base, São Leopoldo, v. 10, p. 117-102, 2013.

BOANARES, D.; AZEVEDO, C. S. The use of nucleation techniques to restore the environment: a bibliometric analysis. Natureza \& Conservação, Rio de Janeiro, v. 12, n. 1, p. 93-98, 2014.

BOCCHESE, R. A.; OLIVEIRA, A. K. M.; FAVERO, S.; GARNÉS, S. J. S.; LAURA, V. A. Chuva de sementes e estabelecimento de plântulas a partir da utilização de arvores isoladas e poleiros artificiais por aves dispersoras de sementes, em áreas de cerrado, Mato Grosso do Sul, Brasil. Revista Brasileira de Ornitologia, São Paulo, v.16, n. 3, p. 207-213, 2008.

BORGES, S. A. A importância do ensino de pós-graduação na formação de recursos 
humanos para o estudo da biodiversidade no Brasil: um estudo de caso na ornitologia. Biota Neotropica, Campinas, v. 8, n. 1, p. 21-27, 2008.

CADENASSO, M. L.; PICKETT, S. T. A.; GROVE, J. M. Dimensions of ecosystem complexity: Heterogeneity, connectivity, and history. Ecological Complexity, Leicester, v. 3, n. 1, p. 1-12, 2006.

CAMPOS, W. K.; NETO, A. M.; PEIXOTO, H. J. C.; GODINHO, L. B.; SILVA, E. Contribuição da fauna silvestre em projetos de restauração ecológica no Brasil. Pesquisa Florestal Brasileira, Colombo v. 32, n. 72, p. 429-440, 2012.

CÉSAR, R. G.; VIANI, R. A. G.; SILVA, M. C.; BRANCALION, P. H. S. Does a native grass (Imperata brasiliensis Trin.) limit tropical forest restoration like an alien grass (Melinis minutioflora P. Beauv.)? Tropical Conservation Science, Menlo Park, v.7, n. 4, p. 639-656, 2014.

CHRISTIANINI, A.V.; GALETTI, M. Spatial variation in post-dispersal seed removal in an Atlantic forest: effects of habitat, location and guilds of seed predators. Acta Oecológica, Montrouge, v. 32, n. 3, p. 328-333, 2007.

DIAS, C. D.; UMETSU, F.; BREIER, T. B. Contribuição dos poleiros artificiais na dispersão de sementes e sua aplicação na restauração florestal. Ciência Florestal, Santa Maria, v. 24, n. 2, p. 501-507, 2014.

FERREIRA, G. A..; MELO, C. Artificial roosts as seed dispersal nuclei in a Cerrado area in Triângulo Mineiro, Brazil. Bioscience Journal, Uberlândia, v. 32, n. 2, p. 514-523, 2016.

FRANCISCO, M. R.; GALETTI, M. Aves como potenciais dispersores de sementes de Ocotea pulchella Mart. (Lauracea) numa área de vegetação de cerrado do sudeste brasileiro. Revista Brasileira de Botânica, São Paulo, v. 25, n. 1, p. 11-17, 2002.

FRANÇOSO, R. D.; BRANDÃO, R.; NOGUEIRA, C. C.; SALMONA, Y. B.; MACHADO, R. B.; COLLI, G. R. Habitat loss and the effectiveness of protected areas in the cerrado biodiversity hotspot. Natureza \& conservação, Rio de Janeiro, v. 13, n. 1, p. 35-40, 2015.

GUEDES, M. C.; MELO, V. A.; GRIFFITH, J. J. Uso de poleiros artificiais e ilhas de vegetação por aves dispersoras de sementes. Ararajuba, Rio de janeiro, v. 5, n. 2, p. 
229-232, 1997.

HARTZ, S. M.; PINHEIRO, G. C.; MENDONÇA-LIMA, A. D.; DUARTE, S. The Potential Role of Migratory Birds in the Expansion of Araucaria Forest. Natureza \& Conservação, Rio de Janeiro, v.10, n. 1, p. 52-56, 2012.

HARZING, A. W. Publish ou Perish. Disponível em: $<$ http://www.harzing.com/pop. htm >Acesso em: 9 out. 2012.

HOLL, K. D. Do Bird perching structures elevate seed rain and seedling establishment in abandoned tropical pasture? Restoration Ecology, Washington, v. 6, n. 3, p. 253 261, 1998.

HORGAN, F. G.; RAMAL, A. F.; VILLEGAS, J. M.; ALMAZAN, M. L. P.; BERNAL, C. C.; JAMORALIN, A.; PASANG,J. M. ORBOC, G. AGREDA, V.; ARROYO, C. Ecological engineering with high diversity vegetation patches enhances bird activity and ecosystem services in Philippine rice fields. Regional Environmental Change, Berlim, p. 01-13, 2016.

IBGE. 2004. Mapa de Biomas do Brasil, primeira aproximação. Rio de Janeiro: IBGE. Disponível em: <www.ibge.gov.br > .

LUNDEBERG, J.; MOBERG. Mobile link organisms and ecosystem functioning: Implications for ecosystem resilience and management. Ecosystems, New York, v. 6, n.1, p. 87-98, 2003.

MANCEBO, D.; VALE, A. A.; MARTINS, T. B. Políticas de expansão da educação superior no Brasil. Revista Brasileira de Educação, Rio de Janeiro, v. 20, n. 60, p. 31-50, 2015.

MARCUZZO, S. B.; GANADE, G.; ARAÚJO, M. M.; MUNIZ, M. F. B. Comparação da eficácia de técnicas de nucleação para restauração de área degradada no sul do Brasil. Floresta, Curitiba, v. 43, n. 1, p. 39-48, 2013.

McCARRON, V. Overcoming the barriers of limited seed dispersal and plant recruitment in a degraded coastal environment. South Australian Naturalist, Adelaide, v. 90, n. 1, p. 05-11, 2016.

MELO, V. A.; GRIFFITH, J. J.; JÚNIOR, P. M.; SILVA, E.; SOUZA, A. L.; GUEDES, M. 
C.; OZÓRIO, T. F. Efeito de poleiros artificiais na dispersão de sementes por aves. Árvore, Viçosa, v. 24, n.3, p. 235-240, 2000.

MINISTÉRIO DO MEIO AMBIENTE/SECRETARIA DE BIODIVERSIDADE E FLORESTAS (MMA/SBF). Avaliação e identificação de áreas e ações prioritárias para a conservação, utilização sustentável e repartição dos benefícios da biodiversidade nos biomas brasileiros. MMA/SBF.Brasília. 2002.

MYERS, N. Biodiversity Hotspots Revisited. BioScience, Oxford, v. 53, n. 10, p. 916$917,2003$.

MYERS, N.; MITTERMEIER, R. A.; MITTERMEIER, C. G.; FONSECA, G. A. B.; KENT, J. Biodiversity hotspots for conservation priorities. Nature, London, v. 403, n. 1, p. 853-858, 2000.

OLSON, D. M.; DINERSTEIN, E.; WIKRAMANAYAKE, E. D.; BURGESS, N. D.; POWELL, G. V. N.; UNDERWOOD, E. C.; D'AMICO, J. A.; ITOUA, I.; STRAND, H. E.; MORRISON, J. C.; LOUCKS, C. J.; ALLNUTT, S T. F.; RICKETTS, T. H.; KURA, Y.; LAMOREUX, J. F.; WETTENGEL, W. W.; HEDAO, P.; KASSEM, K. R. Terrestrial ecoregions of the world: A new map of life on earth. BioScience, Oxford, v. 51, n. 11, p. 933-938, 2001.

PEJCHAR, L.; PRINGLE, R. M.; RANGANATHAN, J.; ZOOKB, J. R.; DURAN, G.; OVIEDO, F.; DAILY, G. C. Birds as agents of seed dispersal in a human-dominated landscape in southern. Biological Conservation, Chapman, v. 141, n. 1, p. 536-544, 2008.

PILLATT, N.; FRANCO, E. T. H.; COELHO, G. C.Dry artificial perches and the seed rain in a subtropical riparian forest. Revista Brasileira de Biociências. Porto Alegre, v. 8, n. 3, p. 246-252, 2010.

PIZO, M. A.; DENIS, A. J.; SCHUPP, E. W.; GREEN, D. A. Westcott ed Frugivory by birds in degraded areas of Brazil. In Seed dispersal - theory and its application in a changing world.Oxford Shire, UK: CAB. International, Oxfordshire, p. 615-627. 2004.

REIS, A.; BECHARA, F. C.; ESPINDOLA, M. B.; VIEIRA, N. K.; SOUZA, L. L. Restauração de áreas degradadas: a nucleação como base para incrementar os processos sucessionais. Natureza \& Conservação, Rio de janeiro, v. 1, n. 1, p. 28-36, 2003.

REIS, A.; BECHARA, F. C.; TRES, D. R.; TRENTIN, B. E. Nucleação: Concepção 
biocêntrica para a restauração ecológica. Ciência Florestal, Santa Maria, v. 24, n. 2 , p. 509-519, 2014.

REIS, A.; BECHARA, F. C.; TRES, D. R. A Nucleação na restauração ecológica de ecossistemas tropicais. Scientia Agricola, Piracicaba, v.67, n. 2, p. 244-250, 2010.

REIS, A.; TRES, R. T.; SCARIOT, E. C. Restauração na Floresta Ombrófila Mista através da sucessão natural. Pesquisa Florestal Brasileira, Brasília, v. 55, n. 1, p. 67-73, 2007.

REY-BENAYAS, J. M.; BULLOCK, J. M.; NEWTON, A. C. Creating woodland islets to reconcile ecological restoration, conservation, and agricultural land use. Frontiers in Ecology and the Environment, Washington, v. 6, n. 6, p. 329-336, 2008.

RODRIGUES, R. R.; LIMA, R. A. F.; GANDOLFI, S.; NAVE, A. G. On the restoration of high diversity forests: 30 years of experience in the Brazilian Atlantic Forest. Biological Conservation, Washington, v. 142, n. 6, p. 1242-1251, 2009.

SANTOS, A. L. F.; AZEVEDO, J. M. L. A pós-graduação no Brasil, a pesquisa em educação e os estudos sobre a política educacional: os contornos da constituição de um campo acadêmico. Revista Brasileira de Educação, Rio de Janeiro, v. 14, n. 42 , p. 534-605, 2009.

SER (Society for Ecological Restoration International) Science \& Policy Working Group. 2004. The SER International Primer on Ecological Restoration (available from http//www.ser.org) accessed in July 2005. Society for Ecological Restoration International, Tucson, Arizona.

SHELDON, K. S.; NADKARNI, N. M.The use of pasture trees by birds in a tropical montane landscape in Monteverde, Costa Rica. Journal of Tropical Ecology, Cambridge, v. 29, n. 05, p. 459-462, 2013.

SHIELS, A. B.; WALKER, L. R. Birds Perches Increase Forest Seeds on Puerto Rican Landslides. Restoration Ecology, Washington, v. 11, n. 4, p. 457-465, 2003.

SILVA, W. R.; PIZO, M. A.; GABRIEL, V. A. Avifauna como promotora da restauração ecológica. In: VON MATTER, S.; STRAUBE, F.; ACCORDI, I.; PIACENTINI, V.; CÂNDIDO-JR, J. F. (Org.). Ornitologia e Conservação: ciência aplicada, técnicas de pesquisa e levantamento. Rio de Janeiro: Technical Books, 2010. p. 507-516. 
SILVEIRA, L. P.; SOUTO, J. S.; DAMASCENO, M. M.; MUCIDA, D. P.; PEREIRA, I. M. Poleiros artificiais e enleiramento de galhada na restauração de área degradada no semiárido da Paraíba, Brasil. Nativa, Sinop, v. 03, n. 03, p. 165-170, 2015.

TOMAZI, A. L.; ZIMMERMANN, C. E.; LAPS, R. R. Poleiros artificiais como modelo de nucleação para restauração de ambientes ciliares: caracterização da chuva de sementes e regeneração natural. Biotemas, Florianópolis, v. 23, n. 1, p. 125-135, 2010.

TRES, D. R.; SANT'ANNA, C. S.; BASSO, S.; LANGA, R., RIBAS, U.; REIS, A. Poleiros Artificiais e Transposição de Solo para a Restauração Nucleadora em Áreas Ciliares. Revista Brasileira de Biociências, Porto Alegre, v. 5, n. 1, p. 312-314, 2007.

VAN-ANDEL, J.; ARONSON, J. Restoration Ecology: Frontier Blackwell Science, Oxford, 2012.

VICENTE, R.; MARTINS, R.; ZOCCHE, J. J.; HARTER-MARQUES, B. Seed dispersal by birds on artificial perches in reclaimed areas after surface coal mining in Siderópolis municipality, Santa Catarina State, Brazil. Revista Brasileira de Biociências, Porto Alegre, v. 8, n. 1, p. 14-23, 2010.

VOGEL, H. F.; SPOTSWOOD, E.; CAMPOS, J. B.; BECHARA, F. Annual changes in a bird assembly on artificial perches: Implications for ecological restoration in a subtropical agroecosystem. Biota Neotropica, Campinas, v.16, n.1, p. 01-09, 2016.

YARRANTON, G. A.; MORRISON, R. G. Spatial dynamics of a primary succession: Nucleation. The Journal of Ecology, London, v. 62, n. 2, p. 417-128, 1974.

ZAHAWI, R. A.; HOLL, K. D.; COLE, R. J.; REID, J. L. Testing applied nucleation as a strategy to facilitate tropical forest recovery. Journal of Applied Ecology, London, v. 1, n. 1, p. 1-9, 2012.

Recebido em: 2016-03-16 Aceito em: 2016-11-09 
Appendix 1. List of works used to carry out this study and shown on the map

(7) MELO, V. A. Poleiros artificiais e dispersão de sementes por aves em uma área de reflorestamento, no estado de Minas Gerais. 1997. 50f. Masters dissertation (Master in Forest Sciences) - Universidade federal de Viçosa, Viçosa, 1997.

(2) BECHARA, F. C. Unidades demonstrativas de restauração ecológica através de técnicas nucleadoras: Floresta Estacional Semidecidual, cerrado e restinga. 2006. 249f. Doctoral thesis (Doctorate in Forest Resources) - Universidade de São Paulo, Piracicaba, 2006.

(4) CECCON, M. F. Efeito de poleiros artificiais na chuva de sementes e restauração de áreas de ocorrência de Floresta Estacional Semidecidual, Fênix-PR. 2006. 41f. Work of course conclusion (Graduation in Biological Sciences) - Universidade Federal do Paraná, Curitiba, 2006.

(9) OLIVEIRA, F. F. Plantio de espécies nativas e uso de poleiros artificiais na restauração de uma área perturbada de cerrado sentido restrito em ambiente urbano no Distrito Federal, Brasil. 2006. 155f. Work of course conclusion (Master in Ecology) - Universidade de Brasília, Brasília, 2006.

(20) ZWIENER, V. P. Efeito de poleiros naturais e artificiais na dispersão de sementes e regeneração da Floresta Atlântica em Antonina, PR. 2006. 39f. Work of course conclusion (Graduation in Biological Sciences) - Universidade Federal do Paraná, Curitiba, 2006.

(1) ALMEIDA, A. Chuva de sementes sob poleiros artificiais em áreas de ocorrência da Floresta Estacional Semidecidual, Fênix-PR. 2008. 44f. Work of course conclusion (Graduation in Biological Sciences) - Universidade Federal do Paraná, Curitiba, 2008.

(5) DIAS, C. R. Poleiros artificiais como catalisadores na recuperação florestal. 2008. 25 f. Work of course conclusion (Graduation in Forest Engineering) - Universidade Federal Rural do Rio de Janeiro, Seropédica, 2008.

(12) SILVA, F. M. Diversidade e dinâmica da vegetação e a chuva de sementes mediada por aves em comunidades secundárias de Floresta Atlântica no sul do Brasil. 2008. 120f. Doctoral thesis (Doctorate in Botany) - Universidade Federal do Rio Grande do Sul, Porto Alegre, 2008.

(18) VICENTE, R. Avifauna e dispersão de sementes com uso de poleiros artificiais em áreas reabilitadas após mineração de carvão a céu aberto, Siderópolis, sul de Santa Catarina. 2008. 81f. Masters dissertation (Master in Environmental Sciences) - Universidade do Extremo Sul Catarinense, Criciúma, 2008.

(3) BRODT, A. A. A utilização de poleiros artificiais na recuperação de matas ciliares e como as aves estão envolvidas neste processo. 2009. 28f. Work of course conclusion (Graduation in Biological Sciences) - Centro Universitário La Salle, Canoas, 2009.

(10) PASSOS, F. B. Avaliação de Solanum lycocarpum A. St.-Hil. (Solanaceae) e de poleiros artificiais como facilitadores na restauração de área perturbada de Cerrado sentido restrito. 
2009. 88f. Masters dissertation (Master in Botany) - Universidade de Brasília, Brasília, 2009.

(8) MUSSI, B. G. Poleiros artificiais como catalisadores do aporte de sementes na restauração florestal. 2010. 29f. Work of course conclusion (Graduation in Forest Engineering) Universidade Federal do Rio de Janeiro, Seropédica, 2010.

(13) SILVA, I. A. Avaliação das técnicas de nucleação para restauração ecológica das matas ciliares do córrego Santo Antônio. 2011. 72f. Specialization monograph (Specialization in Environment and Water Resources) - Faculdade de Tecnologia de Jaú, Jaú, 2011a.

(14) SILVA, J. C. B. Restauração ecológica com uso de poleiros artificiais em área dominada por (Urocbloa bumidicula (Rendle) Morrone \& Zuloaga). 2011. 28f. Masters dissertation (Master in Environmental Sciences) - Universidade Estadual de Maringá, Maringá, 2011b.

(16) SOUZA, R. T. Avaliação do uso de poleiros artificiais em uma área de mata ciliar em processo de regeneração. 2012. 34f. Specialization monograph (Specialization in Ecology and Natural Resource Management) - Universidade do Extremo Sul Catarinense, Criciúma, 2012.

(11) RONCHI, D. L. Restauração de uma área degradada através de poleiros secos como modelo de nucleação. 2013. 30f. Specialization monograph (Specialization in Conservation Biology) - Universidade do Vale do Itajaí, Itajaí, 2013.

(15) SILVEIRA, L. P. Avaliação de algumas técnicas de nucleação em área degradada no Seridó da Paraíba. 2013. 40f. Work of course conclusion (Graduation in Forest Engineering) - Universidade Federal de Campina Grande, Patos, 2013.

(17) TOMAZI, A. L. Restauração ecológica com solarização e poleiros artificiais. 2013. 90f. Masters dissertation (Master in Ecology) - Universidade Federal de Santa Catarina, Florianópolis, 2013.

(6) FERREIRA, G. A. Poleiros artificiais como núcleos de dispersão de sementes e fatores que influenciam este processo em área de cerrado sensu stricto no triângulo mineiro. 2014. 49f. Masters dissertation (Master in Ecology and Conservation of Natural Resources) Universidade Federal de Uberlândia, Uberlândia, 2014.

(19) VOGEL, H. F. Influência de diferentes métodos de restauração ecológica sobre a assembleia de aves em agroecossistema subtropical no Brasil. 2014. 93f. Doctoral thesis (Doctorate in Environmental Sciences) - Universidade Estadual de Maringá, Maringá, 2014. 